\title{
First Clinical Experience of FiLaC TM in Hidradenitis Suppurativa: Is it a Safe and Feasible Treatment Modality?
} Hidraenitis Supprativa'da FiLaC TM'nin Illk Klinik Deneyimi: Güvenli ve Uygulanabilir Bir Tedavi Mi?

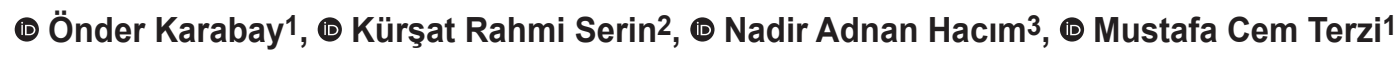 \\ ${ }^{1}$ Yedikule Surp Pırgiç Armenian Hospital, Clinic of General Surgery, İstanbul, Turkey \\ 2İstanbul University Faculty of Medicine, Department of General Surgery, İstanbul, Turkey \\ ${ }^{3}$ Bağcılar Training and Research Hospital, Clinic of General Surgery, İstanbul, Turkey
}

\section{HIIIIII| ABSTRACT}

Aim: Hidradenitis suppurativa (HS) is a disabling and suppurative disease affecting primarily the apocrine-bearing areas. Although wide surgical excision can be performed in later stages, minimally invasive surgical techniques have been developed to limit tissue loss.

Fistula-tract Laser Closure (FiLaC ${ }^{\mathrm{TM}}$ ) has been used to shrink the fistulous tracts of perianal fistula, pilonidal sinus and urethroperineal fistula. However, its usefulness in HS is not yet established.

Method: A retrospective analysis of 14 consecutive patients with HS located at the perianal/perineal and axillary regions was performed. All patients underwent surgery with the FiLaC ${ }^{\text {тм }}$ technique. After treatment, patients were evaluated for the type of clinical response as complete, partial and no response. At the 3rd month control, wound healing without drainage and closure of all external orifices was considered complete response, slight drainage with minimal symptoms was regarded as partial response and persistent and painful symptomatic drainage was evaluated as no response.

Results: There were $12(85.7 \%)$ male and two female patients (14.3\%) with a mean age of $40.3 \pm 8.4$ years. Perianal/perineal and axillary HS was detected in $12(85.7 \%)$ and two (14.3\%) patients, respectively. No intra- and post-operative complications were recorded. Complete and partial responses were seen in four (28.6\%) and eight (57.1\%) patients, respectively. No clinical response was observed in two patients (14.3\%).

Conclusion: The FiLaC ${ }^{\mathrm{TM}}$ technique for the treatment of HS is shown to be safe and feasible. Given the complete and partial responses in most patients, this technique may be used as an adjunctive step in patients with HS with the previous failure of medical and surgical treatments.

Keywords: Hidradenitis suppurativa, laser, fistula-tract laser closure, minimally invasive surgery

\section{|||||||||| ÖZ}

Amaç: Hidradenitis supurativa, öncelikle apokrin bez içeren alanları etkileyen, engelleyici ve akıntılı bir hastalıktır. Daha sonraki aşamalarda geniş cerrahi eksizyon yapılabilmekle birlikte, doku kaybını sınırlamak için minimal invaziv cerrahi teknikler geliştirilmiştir. FiLaC (Fistula-tract Laser Closure) perianal fistül, pilonidal sinüs ve üretroperineal fistülün fistül yollarını küçültmek için kullanılmıştır. Ancak hidradenitis suppurativa'da kullanımı eksiktir.

Yöntem: Perianal/perineal ve aksiller bölgeye lokalize ardışı 14 hidradenitis supurativa hastanın retrospektif analizi yapıldı. Tüm hastalar FiLaC tekniği ile ameliyat edildi. Tedaviden sonra hastalar, klinik yanıt türü açısından tam yanıt, kısmi yanıt ve yanıt yok olarak değerlendirildi. Üçüncü ay kontrolünde akıntısız yara iyileşmesi ve tüm dış ağızların kapanması tam yanıt olarak kabul edildi. Minimal semptomlu hafif akıntı, kısmi yanıt olarak kabul edildi. Kalıcı ve ağrılı semptomatik drenaj ise yanıt yok olarak değerlendirildi.

Bulgular: Hastaların 12'si erkek $(\% 85,7)$ ve ikisi $(\% 14,3)$ kadındı. Ortalama yaş 40,3 $\pm 8,4$ yıldı. Perianal/perineal ve aksiller hidradenitis supurativa, sırasıyla $12(\% 85,7)$ ve iki $(\% 14,3)$ hastada mevcuttu. İntraoperatif veya postoperatif bir komplikasyon görülmedi. Tam ve kısmi yanıt, sırasıyla dört $(\% 28,6)$ ve sekiz $(\% 57,1)$ hastada görüldü. İki $(\% 14,3)$ hastada ise klinik olarak yanıt yoktu.

Sonuç: Hidradenitis supurativa tedavisinde, FiLaC tekniğinin güvenli ve uygulanabilir olduğu gösterilmiştir. Hastaların çoğunda tam ve kısmi yanıtların varlı̆̆ından dolayı, bu teknik daha önce tıbbi ve cerrahi tedavilerde başarısız olan hidradenitis supurativa hastalarında yardımcı bir adım olarak kullanılabilir.

Anahtar Kelimeler: Hidradenitis supurativa, lazer, FiLaC, minimal invaziv cerrahi 


\section{Introduction}

Hidradenitis suppurativa (HS) is a chronic, suppurative skin disease characterised by the formation of subcutaneous nodules, cysts, abscesses and sinuses especially in apocrine gland-bearing areas such as the axilla, groin and perineum. In advanced and chronic stages of HS, uncontrolled infections with the subcutaneous tracts usually lead to fistula formation. ${ }^{1,2}$

Its treatment modality varies depending on severity. Deroofing, excision, carbon dioxide laser vaporisation and electrosurgery are usually recommended when all conservative treatments failed; besides, all these techniques are invasive and painful methods with significant recurrence rates. Endoscopic or less invasive techniques using laser technology have been reported in deep and subcutaneous lesions recently with variable success rates. ${ }^{3-5}$

Fistula-tract Laser Closure (FiLaC ${ }^{\mathrm{TM}}$, Biolitec, Germany), a novel technique, has been used in the treatment of perianal fistula, pilonidal sinus and urethroperineal fistula. ${ }^{1,6,7}$ In this technique, a laser probe is introduced from the openings to destroy the fistulous epithelium and obliterate it by shrinking the tissues around the fistula at $360^{\circ}$ continuously., However, to our knowledge, no study has focused on the effect of the FiLaC technique on HS. Thus, in this paper, we reported the first clinical use of the FiLaC technique in patients with HS.

\section{Material and Methods}

This study retrospectively analysed data of 14 consecutive patients with HS located in the perianal/perineal and axillary regions between January 2016 and December 2019. All patients underwent surgery with the FiLaC technique after the failure of previous medical therapies including topical and systemic antibiotics, anti-inflammatory medicines, topical retinoids and surgical therapy including seton placement and abscess drainage.

This retrospective study was approved by the local institutional ethical committee (approval number: 2020/32). All patients gave their written consent.

Hurley classification system was used for identifying the severity of HS. Patients with abscess formation without sinus tracts and cicatrisation were considered as stage 1 . Patients with recurrent abscesses with tract formation and cicatrisation were evaluated as stage 2 and those with diffuse or near-diffuse involvement or multiple interconnected tracts and abscesses across the entire area were regarded as stage 3.

\section{Surgical technique}

A radial-emitting laser probe (Leonardo $®$, dual 45-diode laser, wavelength of $1470 \mathrm{~nm}$, continuous energy of 10
W) was used for the FiLaC technique. The patients were positioned in lithotomy under general anaesthesia. After widening and debridement of the external orifices of the fistula tract by curettage, a stylet was used to determine the length and direction of the tracts. The laser probe was inserted into the fistula tract (Figure 1) based on the measurements obtained by using the stylet. In the presence of multiple external orifices, more than one stylet was used (Figure 2a) before the probe insertion (Figure 2b). For axillary lesions, the same steps were followed (Figure 3a, b). Then, the activated probe was pulled back at a speed of $1 \mathrm{~mm} / \mathrm{s}$ until its evacuation from the external orifice. The orifice was left open behind.

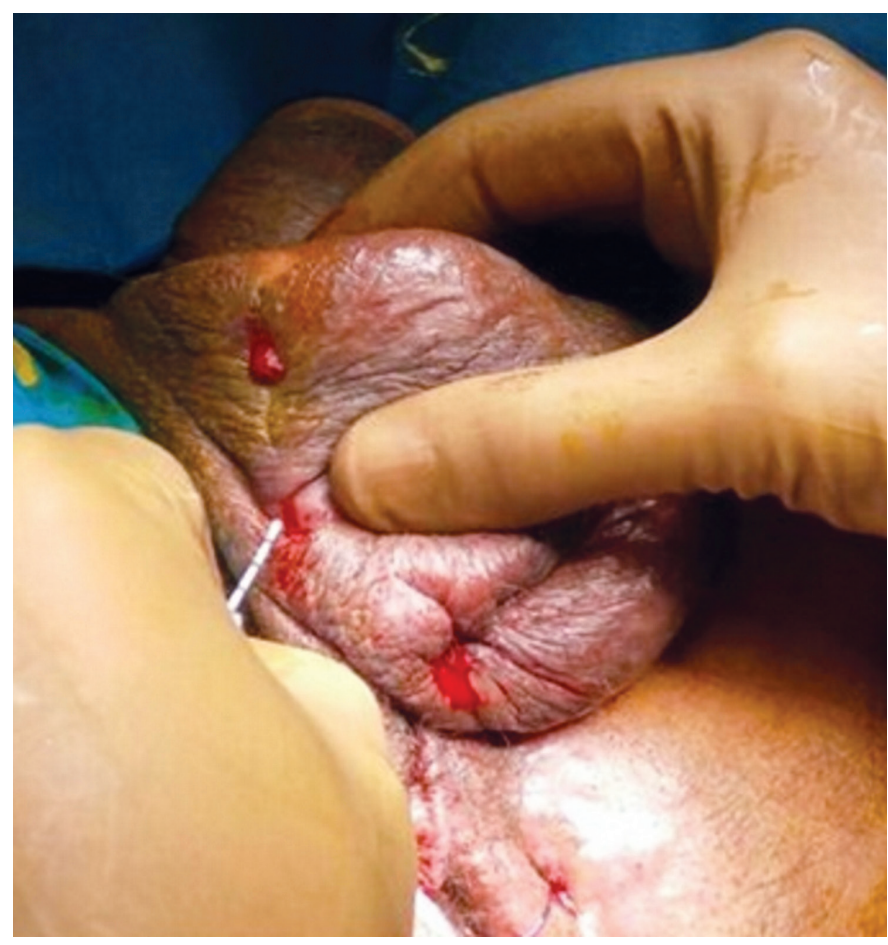

Figure 1. Fistulous openings extending into the scrotum. Application of the laser probe from one of the openings

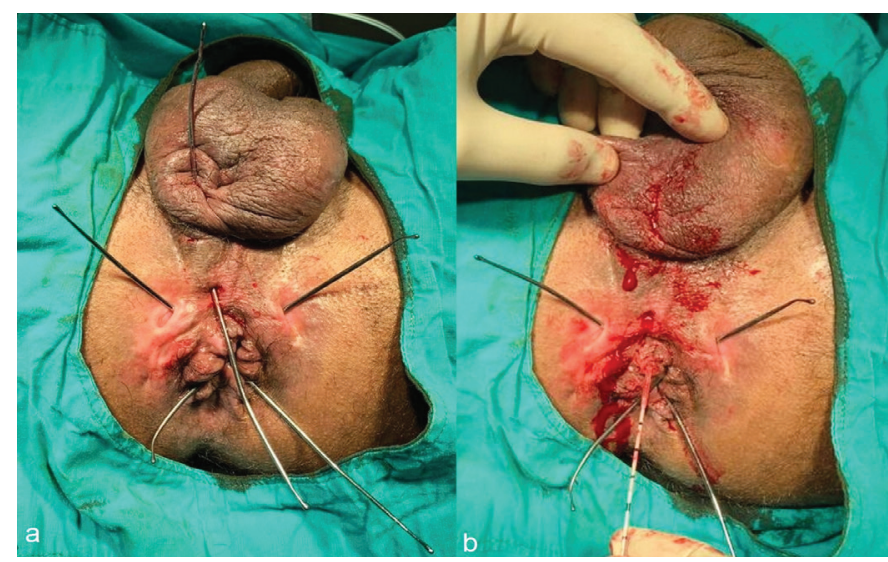

Figure 2. a) Fistulous openings at the perianal region and the scrotum. b) Application of the laser probe from one of the openings 
All patients were discharged on the same day of surgery with antibiotics (ciprofloxacin plus metronidazole). Wound management was recommended by applying wet gauzes once a day for at least 4 weeks postoperatively. For perianal/ perineal HS, sitz baths with warm water once a day was recommended.

After discharge, patients were followed for complications, treatment outcomes such as wound healing and drainage from the orifices and recurrences in the post-operative $1^{\text {st }}$ and $3^{\text {rd }}$ months. Then, follow-up examinations were performed annually.

"Complete response", i.e. wound healing without drainage and closure of all external orifices at the $3^{\text {rd }}$ month control, was regarded as the primary outcome (Figure 4). Slight drainage with minimal symptoms was regarded as "partial response". Persistent and painful symptomatic drainage requiring additional surgical treatment was evaluated as "no response". ${ }^{7}$

Demographic data (i.e. age and sex), clinical features (i.e. disease location, treatment outcomes and follow-up duration in months) and operative findings (i.e. operative time in minutes) were recorded using the patients' medical files.

Normally distributed continuous variables were expressed as mean \pm standard deviation. Median with ranges was

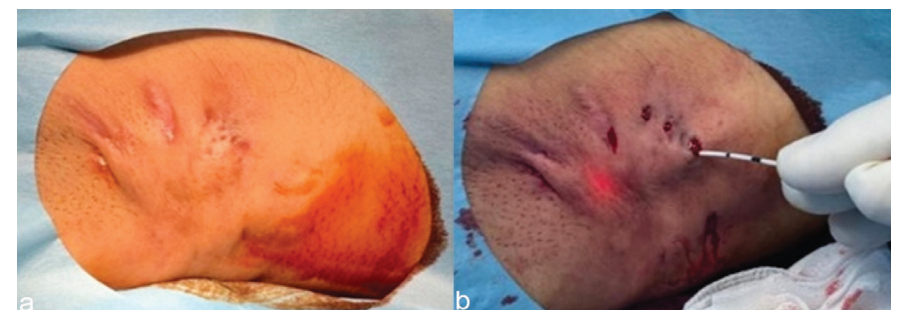

Figure 3. a) Multiple sinuses and corresponding fistulas at the axilla. b) Application of the laser probe from one of the openings

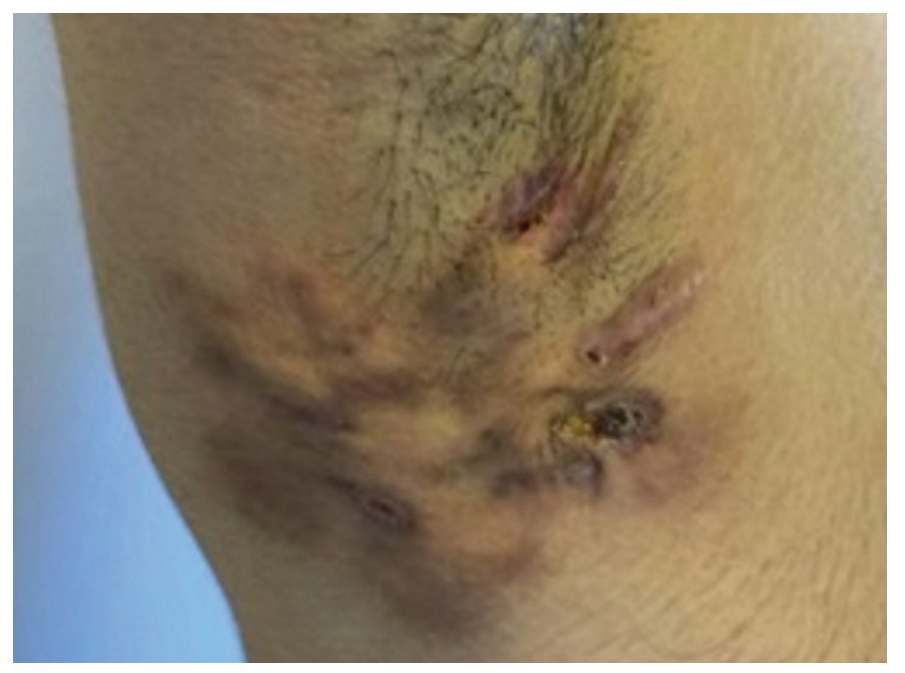

Figure 4. Final appearance of the axilla at the first month of follow-up used for continuous variables without normal distribution. Categorical variables were expressed as frequencies and percentages.

\section{Results}

Of the 14 patients, 12 (85.7\%) were male and two were female (14.3\%), with a mean age of $40.3 \pm 8.4$ years. Demographic and clinical characteristics are shown in the Table 1.

Twelve (85.7\%) patients had perianal/perineal HS, and the remaining two (14.3\%) presented axillary HS. Nine patients (64.2\%) were at Hurley stage 2 and five patients (35.8\%) were at stage 3. No intraoperative or postoperative complications were observed in our patient series. The mean operation time and median follow-up duration were $32.6 \pm 7.3 \mathrm{~min}$ and 13.5 (range 3-26) months, respectively. The total healing rate was $28.6 \%$, as four patients demonstrated "complete response", eight (57.1\%) patients showed "partial response" and two (14.3\%) patients did not benefit from the treatment ("no response").

\section{Discussion}

To the best of our knowledge, this is the first case series of FiLaC in patients with HS. The present results showed that FiLaC, as a minimally invasive surgery, may be used for the treatment of HS. Although nearly half of the patients showed partial benefit from the FiLaC technique, complete response in one-quarter of the patients may support its use in chronic fistulous diseases such as HS.

Table 1. Demographic and clinical characteristics of the patients $(n=14)$

\begin{tabular}{llllll} 
No & $\begin{array}{l}\text { Age } \\
\text { (year) }\end{array}$ & Sex & Location & $\begin{array}{l}\text { Hurley } \\
\text { classification }\end{array}$ & $\begin{array}{l}\text { Clinical } \\
\text { response }\end{array}$ \\
1 & 43 & M & PP & 2 & Partial \\
2 & 35 & M & PP & 3 & Partial \\
3 & 54 & M & PP & 2 & No response \\
4 & 51 & M & PP & 2 & Complete \\
5 & 27 & M & PP & 3 & Partial \\
6 & 26 & M & PP & 2 & Partial \\
7 & 29 & F & A & 2 & Partial \\
8 & 33 & M & PP & 2 & Partial \\
9 & 50 & M & PP & 3 & No response \\
10 & 48 & M & PP & 3 & Partial \\
11 & 44 & M & PP & 2 & Complete \\
12 & 37 & F & PP & 3 & Complete \\
13 & 41 & M & PP & 2 & Partial \\
14 & 46 & M & A & 2 & Complete \\
\hline
\end{tabular}

M: Male, F: Female, PP: Perianal/perineal, A: Axilla 
The energy radiating from the laser probe induces destruction of the epithelium and the shrinkage of the tract within the depth of 2-3 $\mathrm{mm}$ of the surrounding tissues. This action mechanism has been thought to be the major advantage of electrocoagulation. ${ }^{6}$ All these mechanisms of the FiLaC technique support its use in several fistulous diseases.

At present, no surgical technique meets the ideal standard for HS; therefore, we tried to adopt the FiLaC technique that has been used for chronic fistulous diseases such as fistulain-ano and pilonidal sinus disease for HS. ${ }^{[1]}$ As less invasive approaches including intralesional radiofrequency ablation, endoscopic cauterisation via a monopolar electrode or laser energy and carbon dioxide laser have been used for the surgical treatment of HS recently, ${ }^{3-5}$ we aimed to obtain the possible benefits of the FiLaC technique to obliterate sinuses as in other diseases. In studies using 1064-nm Nd:YAG laser for the treatment of HS, this type of laser causes selective photothermolysis of follicular units and destruction of organised inflammatory lesions. ${ }^{8}$ The FiLaC technique has used a 1070-nm diode laser. Given the almost similar technical features, both techniques may function by using the same action mechanisms. However, controlled studies are needed to reach more meaningful conclusions.

Higher complications and recurrences have been implied in patients with HS undergoing surgery. In a systematic review, Bouazzi ${ }^{9}$ reported that the overall mean complication and recurrence rates were $24 \%$ and $20.1 \%$, respectively. In addition to resection of healthy tissues for the reconstruction of surgical defects, restrictions in the mobility of the upper extremities have been also mentioned after the surgical treatment of axillary HS. ${ }^{10}$ Although two-thirds of the patients were satisfied with the surgical treatment of HS, the recurrence rate was $35 \%$ after one-stage surgical closure. ${ }^{11}$ Post-operative recurrences were seen in $54.2 \%$ of 48 patients who had undergone 91 wide excisions. ${ }^{12}$ Therefore, multiple surgical interventions with reconstructions may be needed for complete healing in patients with HS. Considering this issue, the FiLaC technique may be regarded as an adjunct to surgical treatments because of its benefits, such as less invasiveness and absence of tissue loss.

However, the FiLaC technique has some drawbacks when used in HS. Exploration of the communicating tracts and destruction of all epithelialised tissues have been reported as the mainstay for the successful surgical treatment of HS. ${ }^{4}$ We and other researchers used blunt probing to identify the exact anatomy of the tracts contrary to Grimstad's study ${ }^{5}$ who used methylene blue. ${ }^{3}$ Thus, the use of methylene blue in association with the FiLaC technique can be tried in future studies. Although we did not evaluate the cost of the technique, such technology has been known to require more expensive equipment. ${ }^{7}$ In addition to the complications and cost concerns, the speed of probe removal and amount of delivered energy are also associated with the use of the FiLaC technique in HS. Thus, prospective studies are needed to clarify these issues.

The retrospective design and small sample size were the main limitations of the study. The short follow-up period to collect data about recurrences and the lack of clinical data about previous dermatological treatments were other limiting factors. As a clinical policy, we did not perform presurgical mapping either by methylene blue or by imaging techniques. This issue can be a weak study point. However, being the first to report the clinical use of the FiLaC technique in patients with HS was the major strength of our study.

In conclusion, the FiLaC technique for treatment of HS was shown to be safe and feasible. In addition, complete healing in nearly one-quarter of the patients, partial symptomatic relief in more than half of the patients and the lack of aggressive tissue destruction leading to daycare surgery were other advantages. The findings of this small case series study suggest that this technique may be used as an adjunctive step in patients with HS in whom previous medical and surgical treatments failed. However, prospective randomised largescale studies are needed to clarify its clinical efficiency and potential issues.

\section{Ethics}

Ethics Committee Approval: This retrospective study was approved by the local institutional ethical committee (approval number: 2020/32).

Informed Consent: All patients gave their written consent. Peer-review: Internally and externally peer reviewed.

\section{Authorship Contributions}

Surgical and Medical Practices: Ö.K., K.R.S, N.A.H., M.C.T., Concept: Ö.K., K.R.S, M.C.T., Design: Ö.K., N.A.H., M.C.T., Data Collection or Processing: K.R.S., N.A.H., Analysis or Interpretation: Ö.K., M.C.T., Literature Search: Ö.K., N.A.H., Writing: Ö.K., K.R.S., N.A.H, M.C.T.

Conflict of Interest: No conflict of interest was declared by the authors.

Financial Disclosure: The authors declared that this study received no financial support.

\section{References}

1. Gys B, De Hous N, Hubens G, De Win G, Komen N. Fistula-tract Laser Closure (FiLaC ${ }^{\mathrm{TM}}$ ) for complex urethroperineal fistula. Acta Chir Belg 2018;118:398-401

2. Patil S, Apurwa A, Nadkarni N, Agarwal S, Chaudhari P, Gautam M. Hidradenitis Suppurativa: Inside and Out. Indian J Dermatol 2018;63:918. 
3. Esposito C, Del Conte F, Cerulo M, Coppola V, Esposito G, Ricciardi E, Castagnetti M, Fabbrocini G, Escolini M. Pediatric Endoscopic Hidradenitis Treatment: A New Minimally Invasive Treatment for Pediatric Patients with Hidradenitis Suppurativa. J Laparoendosc Adv Surg Tech A 2020;30:464-470.

4. Subhadarshani S, Gupta V, Taneja N, Yadav S, Gupta S. Efficacy and Safety of a Novel Method of Insulated Intralesional Radiofrequency Ablation for Deep Dermal and Subcutaneous Lesions: A 3-Year Institutional Experience. Dermatol Surg 2018;44:714-720.

5. Emtestam L, Lapins J, Sartorius K. Carbon Dioxide Laser Treatment Using Methylene Blue-Assisted Sinus Tract Identification in Hidradenitis Suppurativa. Dermatol Surg 2017;43:604-605.

6. Dessily M, Charara F, Ralea S, Allé JL. Pilonidal sinus destruction with a radial laser probe: technique and first Belgian experience. Acta Chir Belg 2017;117:164-168.

7. Terzi MC, Agalar C, Habip S, Canda AE, Arslan NC, Obuz F. Closing Perianal Fistulas Using a Laser: Long-Term Results in 103 Patients. Dis Colon Rectum 2018;61:599-603.
8. Xu LY, Wright DR, Mahmoud BH, Ozog DM, Mehregan DA, Hamzavi IH. Histopathologic study of hidradenitis suppurativa following longpulsed 1064-nm Nd:YAG laser treatment. Arch Dermatol 2011;147:21-8.

9. Bouazzi D, Chafranska L, Saunte DML, Jemec GBE. Systematic Review of Complications and Recurrences After Surgical Interventions in Hidradenitis Suppurativa. Dermatol Surg 2020 Feb 11. doi: 10.1097/ DSS.0000000000002323.

10. Shavit E, Pawliwec A, Alavi A, George R. The surgeon's perspective: a retrospective study of wide local excisions taken to healthy subcutaneous fat in the management of advanced hidradenitis suppurativa. Can J Surg 2020;63:E94-9.

11. Fertitta L, Hotz C, Wolkenstein P, Méningaud JP, Sawan D, Hersant B, Sbidian E. Efficacy and satisfaction of surgical treatment for hidradenitis suppurativa. J Eur Acad Dermatol Venereol 2020;4:839-845

12. Walter AC, Meissner M, Kaufmann R, Valesky E, Pinter A. Hidradenitis Suppurativa After Radical Surgery-Long-Term Follow-up for Recurrences and Associated Factors. Dermatol Surg 2018;44:1323- 